'Why is there no NATO in Asia?'

Revisited: Prospect theory, balance of threat, and US alliance strategies

He, Kai; Feng, Huiyun

Published in:

European Journal of International Relations

DOI:

$10.1177 / 1354066110377124$

Publication date:

2012

Document version

Early version, also known as pre-print

Citation for published version (APA):

He, K., \& Feng, H. (2012). 'Why is there no NATO in Asia?': Revisited: Prospect theory, balance of threat, and US alliance strategies. European Journal of International Relations, 18(2), 227-250.

https://doi.org/10.1177/1354066110377124 


\section{European Journal of International Relations \\ http://ejt.sagepub.com/}

'Why is there no NATO in Asia?' revisited: Prospect theory, balance of threat, and US alliance strategies

Kai He and Huiyun Feng

European Journal of International Relations 2012 18: 227 originally published online 27 January 2011

DOI: $10.1177 / 1354066110377124$

The online version of this article can be found at:

http://ejt.sagepub.com/content/18/2/227

Published by:

(S)SAE

http://www.sagepublications.com

On behalf of:

ecpr

internati zus

Standing Group on International Relations of the ECPR

Additional services and information for European Journal of International Relations can be found at:

Email Alerts: http://ejt.sagepub.com/cgi/alerts

Subscriptions: http://ejt.sagepub.com/subscriptions

Reprints: http://www.sagepub.com/journalsReprints.nav

Permissions: http://www.sagepub.com/journalsPermissions.nav

Citations: http://ejt.sagepub.com/content/18/2/227.refs.html

>> Version of Record - May 29, 2012

OnlineFirst Version of Record - Jan 27, 2011

Downloaded from ejt.sagepub.com at Utah State University on May 29, 2012

What is This? 


\title{
'Why is there no NATO in Asia?' revisited: Prospect theory, balance of threat, and US alliance strategies
}

European Journal of International Relations I8(2) 227-250

(C) The Author(s) 2010 Reprints and permissions: sagepub. co.uk/journalsPermissions.nav DOI: |0.1 I77//354066| I0377/24 ejt.sagepub.com

@SAGE

\section{Kai He}

Utah State University, USA

\section{Huiyun Feng}

Utah State University, USA

\begin{abstract}
Why did the US prefer multilateral alliances in Europe, but bilateral alliances in Asia after World War II? Rationalists and constructivists debate the impact of power, institutions, and identities in explaining this highly contested question. We introduce a new argument embedded in prospect theory from political psychology - a prospect-threat alliance model - to account for the variation in US alliance strategy toward Europe and Asia after World War II. Through setting the threat level as a reference point for leaders' prospects of gains or losses, we suggest: (I) high threats frame decision-makers in a domain of losses, and multilateral alliances become a favorable alliance choice because states are more likely to take the risk of constraining their freedom of action in return for more help from multiple allies as well as for avoiding further strategic losses; (2) low threats position leaders in a domain of gains, and bilateral alliances win out because states are risk-averse in terms of maintaining their freedom of action in seeking security through alliances with fewer allies. US alliance policy toward Asia after World War II is a within-case analysis that tests the validity of the prospect-threat alliance model.
\end{abstract}

\section{Keywords}

balance of threat, NATO in Asia, prospect theory, SEATO, US alliance strategies

\section{Corresponding author:}

Kai He, Political Science Department, Utah State University, 0725 Old Main Hill, Logan, UT 84322, USA.

Email: hekai@yahoo.com 


\section{Introduction}

'Why is there no NATO (North Atlantic Treaty Organization) in Asia?' (Acharya, 2005; Hemmer and Katzenstein, 2002). It is a highly debated question among International Relations scholars. Rationalists, especially neorealists and neoliberals, suggest power disparity and institutional efficiency arguments to account for different US alliance strategies after World War II, that is, bilateralism in Asia but multilateralism in Europe (Crone, 1993; Ikenberry, 2003; Press-Barnathan, 2000/1; Weber, 1992). Constructivists contend that the different densities of collective identity between the US and its allies in Europe versus Asia explain the variation in US alliance strategies (Hemmer and Katzenstein, 2002). While the US prefers a multilateral alliance, that is, NATO, with its European partners who share a common identity, bilateral alliances are designed for dealing with its alien, inferior partners in Asia. ${ }^{1}$

After examining the merits and weaknesses of the prevailing rationalist and constructivist arguments, we introduce a new argument embedded in political psychology - a prospect-threat alliance model - to account for the variation in US alliance strategy in Europe and Asia after World War II. The prospect-threat alliance model combines prospect theory from political psychology and balance of threat theory from political science to explain under what conditions states are more likely to commit to a multilateral alliance rather than a bilateral one. It suggests that different levels of threat from the international system shape leaders' decisions in choosing bilateral versus multilateral alliances to pursue security. By setting the threat level as a reference point for leaders' prospects of gains or losses, the prospect-threat alliance model argues that (1) high threats frame decision-makers in a domain of losses, and multilateral alliances become a favorable alliance choice because states are more likely to take the risk of constraining their freedom of action in return for more help from multiple allies as well as for avoiding further losses in the strategic competition with rivals; (2) low threats position leaders in a domain of gains, and bilateral alliances win out because states are risk-averse in terms of maintaining their freedom of action in seeking security through alliances with fewer allies.

Alliance formation is a complex and sophisticated foreign policy outcome influenced by material, ideational, and domestic factors. US postwar decisions regarding alliance strategies are by no means the one single factor accounting for different patterns of alliance formation in Europe and Asia, which are determined by the interactions of state foreign policy behavior. But focusing on different US alliance strategies - state behavior - does shed some light on the interaction outcomes of state behavior. In addition, the prospectthreat alliance model does not deny the merits of the existing rationalist and constructivist approaches in explaining different US postwar alliance strategies in Europe and Asia. It does provide an alternative explanation through a psychological lens, which complements both rationalism and constructivism in the study of alliance formation.

There are two caveats in this research. First, the prospect-threat alliance model is more appropriate in explaining great powers' alliance strategies than small powers' alliance behavior. Although it is important to attract support from small powers in forming an alliance, great powers normally play the decisive role in determining the design as well as the nature of alliances. Small or weak powers sometimes have different motivations from great powers to join alliances or alignments. Besides balancing against threats as great powers normally do (Walt, 1987), small states may join alliances for seeking 
profits (Schweller, 1994), for overcoming fears of abandonment (Cha, 2000), for raising voice opportunities (Grieco, 1995), or for managing potential rivals (Weitsman, 2004). While acknowledging different motivations between great powers and small powers in alliance formation, we focus on explaining how great powers - the United States in this research - set up different types of alliance when facing external threats. Second, there are distinctions between wartime alliances and peacetime alliances (Russett, 1968; Weitsman, 2004). This research focuses on alliances formed in peacetime, although the strategic competition between the United States and the Soviet Union occasionally intensified toward a wartime level during the Cold War era.

\section{Explaining different US alliance strategies: Power, efficiency, and identity}

\section{Rationalist arguments}

The power disparity argument contends that different levels of power asymmetry between the US and its potential allies determine how the US constructed military alliances, either bilaterally or multilaterally. As Weber suggests, the US treated the European countries as great powers that only temporarily faced economic and military difficulties after World War II. A US multilateral alliance through NATO and economic aid through the Marshall Plan were aimed at reviving the great power status of the Western European states so that they could stand up to threats from the Soviet Union (Weber, 1992).

However, the power disparity between the US and Asian countries was so huge that Asian countries could not offer any meaningful economic and military support to the United States. Building a multilateral alliance such as an Asian NATO was not rational behavior, because the US could not pool resources from its Asian allies to serve its burden-sharing purpose. ${ }^{2}$ Bilateral alliances became the preferable alliance strategy for the US in Asia.

From the same rationalist school liberals focus on the institutional efficiency of multilateralism in explaining different postwar alliance formation strategies by the United States. Ikenberry (2003: 50) suggests that multilateralism can help the leading state 'lock other states into stable and predictable policy orientations, thereby reducing its need to use coercion'. In postwar Europe the US had 'an elaborate agenda for uniting the European states, creating an institutional bulwark against communism, and supporting centrist democratic regimes ... [and these ambitious lock-in goals] could not simply be realized through the brute exercise of power'(Ikenberry, 2003: 58). Therefore, a NATO-type, multilateral security institution became a more efficient institutional tool for the US to dominate Europe in the postwar era. In contrast, the US did not have similar goals in Asia as it did in Europe. American extreme hegemony in Asia also permitted the United States to choose rationally a series of bilateral alliances rather than an Asian NATO because multilateralism would constrain US policy autonomy more than bilateralism.

There are at least three problems with these rationalist explanations. First, if power disparity really matters for the US to determine its alliance partners, why did the US agree to include weak powers, such as Iceland, Portugal, Turkey, and Greece, in NATO? It is understandable that the United Kingdom, France, and even West Germany had the potential to share US burdens in Europe. But how the small Western European powers could materially contribute to the US multilateral alliance against the Soviet Union is 
still not clear. Further, the United States initiated in 1947 a similar collective security alliance, the Organization of American States (OAS) — or the so-called Rio Pact — with some weak powers in Latin America. In Asia the United States also established two multilateral alliances, the Australia, New Zealand, United States Security Treaty (ANZUS) and the Southeast Asian Treaty Organization (SEATO), in the 1950s. However, the US did not include Japan, the most advanced economic and military power in Asia, in either of them. It seems that the power disparity and burden-sharing arguments cannot fully explain the variation in US alliance strategies between Europe and Asia.

Second, the institutional efficiency argument faces a problem of indeterminacy. Although multilateralism is a convenient tool for the hegemon to dominate or 'lock in' others, it is still unclear when the hegemon will choose multilateralism rather than bilateralism or unilateralism. If multilateralism is a more efficient tool for the US to exercise its hegemonic power, Asia should be the place to employ this strategy because the US was a more predominant power in Asia than in Europe. The preponderant power of the US in Asia would give the US more leverage to construct any rules and norms it preferred and to punish any free-riding behavior without facing substantial resistance and challenge due to the huge power asymmetry between the United States and other Asian countries. However, the US did not choose multilateralism or to 'lock in' other countries in Asia. The mere institutional efficiency argument fails to fully address this puzzle.

Last, but not least, both the power disparity and institutional efficiency arguments encounter an expected-utility bias. These explanations assume that the US leaders could weigh the utility of bilateralism versus multilateralism and select the strategy with the highest expected utility. As Ikenberry suggests, the US wanted more from Europe than from Asia due to the power and efficiency considerations, so it chose multilateralism to maximize the expected utility in Europe but not in Asia (Ikenberry, 2004). The major problem for the expected-utility argument in general and for Ikenberry's NATO explanation in particular lies in the presumed preference ordering. How and why the US wanted more from Europe than from Asia is problematic in the first place. The US experienced two bloody wars, the Korean War and Vietnam War, in Asia after World War II. If regional stability was what the US desired in the postwar era, Asia was at least as important as Europe.

Besides the power disparity and institutional efficiency arguments, there are two other possible rationalist explanations which focus on geopolitical variables, geography and polarity, in shaping different alliance strategies of the United States in the postwar era. ${ }^{3}$ One is to suggest that Europe is a contiguous land theater while Asia is a maritimeand-land combined theater. From a military operational perspective, forming collective multilateral arrangements makes more sense in Europe than in Asia since multilateral military coordination and cooperation are more efficient in a contiguous land theater. In addition, there were different regional power configurations in Asia and Europe after World War II. In Europe, there was a clear bipolar regional system led by the United States and the Soviet Union. In Asia, the power configuration was more complicated because of the surprising victory of the Chinese Communist Party in mainland China. While a bipolar system in Europe facilitates states in forming multilateral collective arrangements, a tripolar regional system in Asia complicates states' choices for multilateral alliances.

The geography-based explanation is interesting. It may explain why the United States was reluctant to accept Australia's multilateral alliance proposal in the late 1940s. However, it cannot explain why the United States proposed the 'Pacific Pact' after the 
outbreak of the Korean War and the 'united action' plan under a collective security defense arrangement after the siege of Dienbienphu in 1954. Both aimed at forming multilateral alliances in Asia. The power-polarity explanation is sensible. However, China's 'leaning to one side' foreign policy in the early 1950s was rooted in the ideological antagonism between communism and capitalism in Asia. The Sino-Soviet split did not happen until the late 1950s. The Asian tripolar argument may explain some geopolitical difficulties of multilateral arrangements led by the United States in Asia after the 1950s. However, it has a difficult time when applied to Asia in the early 1950s where ideologybased bipolarity was more prominent.

\section{Constructivist arguments}

Constructivists challenge the presumed, material-based, interests of states suggested by rationalists. They argue that state interests are constituted by norms, identities, and other ideational factors. In the study of different US alliance strategies in Europe and Asia, there are two prevailing identity-based arguments, the collective identification explanation and the Asian uniqueness hypothesis. Hemmer and Katzenstein (2002: 275-276) suggest that US perceptions of collective identity played an indispensable role in determining different US alliance strategies in Europe and Asia. Multilateralism requires a strong sense of collective identity while bilateralism does not. In Europe, 'shaped by racial, historical, political, and cultural factors, US policymakers saw their potential European allies as relatively equal members of a shared community'. Therefore, multilateralism, for example the formation of NATO, prevailed over bilateralism in postwar Europe. However, the US saw its potential allies in Asia as 'part of an alien and, in important ways, inferior community'. ${ }^{4}$ Bilateral alliances thereby became a useful tool for the US to maintain its superior status versus its allies in Asia.

Challenging Hemmer and Katzenstein's American-centric argument, Acharya suggests that the absence of a collective security alliance in Asia after World War II can be explained by the uniqueness of Asian regionalism. Acharya argues that the Asian unique norms against collective defense were the major reason for the failure of building an Asian NATO during the Cold War. Differing from their European counterparts, the newly-independent Asian countries saw US-led, multilateral security institutions as a new form of great power dominance and intervention. Resistance to the localization of global norms, especially an emphasis on sovereignty and non-intervention, made the NATO norm difficult to diffuse and become embedded in Asian regional practices. In particular, India under Nehru was the normative leader of anti-collective defense norms in Asia. And the final demise of SEATO stemmed from the 'lack of regional representation and participation' (Acharya, 2005: 8-9).

The identity-driven and norm-based constructivist explanations truly pave a new path in the research on comparative regionalism in Europe and Asia. However, these constructivist arguments also become problematic under further scrutiny. First, if a collective identity shared by America and the European powers determines the US embrace of multilateralism in Europe, why did the United States not form NATO or a similar multilateral security institution before World War II? It is true that President Wilson was the strongest advocate of the League of Nations, but the US failed to join it due to domestic opposition in 1919. How and why the US changed its identity to embrace 
NATO after World War II are unanswered questions for constructivists. In addition, if collective identity between the US and European states really matters, why did the US not build a cross-Atlantic economic organization, that is, an economic NATO, or why did the US not just become a member of the European Community or the later European Union?

Second, the Asian-norm argument may explain why some countries, such as India and Indonesia, refused to join the US-led SEATO, but it fails to address why other Asian countries (Thailand and the Philippines) supported the collective defense idea from the beginning. Not all Asian countries rejected military alliances with great powers, especially with the US, during the Cold War. In a bilateral alliance the non-intervention and sovereignty norms actually face more severe pressures than in a multilateral institution. After the establishment of SEATO in 1955, all Asian members demanded a NATO-type collective defense pact with the United States. However, it was the United States that refused to upgrade the 'consultative decision-making process' within SEATO to an automatic, NATO-type, defensive alliance. Therefore, the anti-collective security norm may well partly explain the limited scope and representation of SEATO in Asia, but it is weak in accounting for the rise and fall of multilateralism, manifested in postwar Asia through SEATO.

Third, both the collective identity and Asian-norm arguments face difficulties in explaining the transformation of identities and norms over time. If collective identity is the prerequisite of US multilateralism, why did the US support multilateral economic and security institutions such as Asian Pacific Economic Cooperation (APEC) and the ASEAN Regional Forum (ARF) in Asia after the Cold War? Did the United States really change its perception of identity regarding its Asian partners from inferior, alien states to equals after the Cold War? More importantly, what factors drive such identity transformation is still an unanswered question for constructivists.

In sum, the existing rationalist and constructivist explanations for the absence of an Asian NATO are incomplete at best. The power disparity and institutional efficiency arguments failed to specify causal mechanisms between US strategic preferences and different US alliance strategies. The two constructivist arguments based on identities and norms are also problematic in explaining the formation and transformation of America's collective identity and Asian norms. Therefore, we introduce an alternative, psychologyembedded, explanation - a prospect-threat alliance model — to address the deficiencies of the existing theories.

It is worth noting that the prospect-threat alliance model does not suggest that the existing rationalist and constructivist arguments are totally wrong in explaining different US alliance strategies in Asia and Europe after World War II. Many factors, both material and ideational, shaped US policymakers' alliance decisions in the postwar era. Rather than refuting other explanations, we intend to complement the existing arguments by suggesting a new potential research angle to explain different alliance strategies of the United States after World War II.

\section{The prospect-threat alliance model:Threats and risk-taking behavior in alliances}

As Glenn Snyder (1997) points out, the study of military alliances attracts less attention than it deserves in international relations. For example, Stephen Walt (1987) suggests 
that states balance against the most threatening states under the anarchic international system. However, Walt's balance of threat theory does not specify how states balance threats, that is, how states form different alliances to cope with threats. What most IR scholars focus on is what states balance against, power or threat, or whether states balance or bandwagon, but not how states balance through alliances. Combining insights from balance of threat theory and prospect theory, the prospect-threat alliance model examines how states balance against threats, either through bilateral alliances or multilateral alliances, or both.

Prospect theory is a behavioral theory of decision-making under conditions of risk introduced by Daniel Kahneman and Amos Tversky (1979) through laboratory experiments. Risk refers to the probability of likely losses rather than likely gains associated with a decision; the higher the probability of losses, the riskier the decision. ${ }^{5}$ They find that how people interpret their situation for making choices, as in a domain of gains or losses, influences how they behave in terms of risk aversion or risk acceptance. Prospect theory argues that people tend to evaluate choices with respect to a reference point. People choose risk-averse behavior in a domain of gains but risk-acceptant behavior in a domain of losses. ${ }^{6}$ If people are in an advantageous situation (a domain of gains), they are more likely to behave cautiously (risk-aversely) in order to protect their gains and avoid losses. However, when people are in a disadvantageous situation (a domain of losses), they are more likely to choose risky behavior that may either reverse or worsen their losses. They accept the risk of further losses in order to reverse them, even though in the extreme case the probability of such losses may be greater than the probability of gains (McDermott, 2004: 294). In other words, they choose irrationally by going 'against the odds' of expected utility calculations, as in the case of the debt-ridden lottery player in the domain of losses whose odds (probability) of winning the lottery (achieving gains) are much worse than losing the purchase price (incurring losses) of the lottery ticket.

There are two main reasons for applying prospect theory to analyze a state's different alliance decisions. First, prospect theory can offer an alternative explanation of alliance formation strategy, which complements what expected utility theory cannot explain. Rationalist arguments discussed in this article are mainly based on expected utility theory, which suggests that rational state actors maximize the presumed utility (satisfaction of preferences) in making policy decisions. However, as Waltz (1979) points out, it is not rational for the United States as one of the superpowers to form alliances with weak states since others' support is basically neglected in the bipolar competition between the United States and the Soviet Union. Although Walt's balance of threat theory can explain why the US formed military alliances, that is, to deal with the Soviet threat, it fails to specify how to balance such threats. As rational choice-based models, power disparity and institutional effectiveness arguments cannot fully explain the variation in US alliance strategies in Europe and Asia after World War II.

Challenging the problematic, presumed preferences of rational choice approaches, prospect theory suggests a dynamic way to explain and predict decision-makers' risktaking behavior through determining the domains of choice regardless of whether preferences are known or not. Theoretically, prospect theory can provide an alternative perspective to conventional rational choice approaches in accounting for different US alliance strategies in Asia and Europe. It is worth noting that prospect theory is originally 
a behavioral decision-making theory with individuals as units of analysis in Kahneman and Tversky's experiments. One common criticism of prospect theory in international relations targets the applicability of individual-level theory to state-level behavior. However, as Taliaferro (2004a: 231) points out, 'the growing experimental literature on escalating commitment and investment behavior shows that prospect theory provides a descriptive model for organizational and group decision making'. In his study of interventions in the peripheries by great powers, Taliaferro also applies prospect theory to aggregated, state-level behavior. Here we apply prospect theory to state-level behavior while acknowledging the debatable aggregation problem of using prospect theory in international relations, which is also shared by many utility-based rationalist theories in IR. We assume that states are the unit of analysis just as rationalist theory does in IR. The perceptions and the preferences of states are indicated by individual leaders' statements and speeches and governmental documents.

Second, alliance formation is state behavior under conditions of relatively high uncertainty and complexity, thus involving high levels of risk. As unitary actors in a self-help international system, states prefer solving their problems and dealing with threats by themselves, that is, through internal balancing via military mobilization and arms races. Although external balancing through forming alliances can help states gain security, states are also exposed to high risks of losses in alliances. The principal loss is the highly probable loss of freedom of action, which can take many forms, such as political constraints, military obligations, and even military entrapment. For example, before World War I the European powers formed entangled, overlapping alliances. Consequently, they were entrapped in a war that some states may not have been interested in fighting in the first place. The post-World War II alliance with the United States offered Japan increased security protection during the Cold War. However, Japan also lost a state's normal freedom of action because of its highly constrained foreign and economic policies accompanying the alliance with the United States.

Therefore, an alliance is a double-edged sword for a state in the international system. Balance of threat theory explains why states balance through alliances by focusing on the benefits side of alliances, but it pays less attention to the risky side of alliances regarding a state's probable loss of autonomy. As a theory to explain behavior under risk, prospect theory is fully compatible with the study of alliance formation and can play a complementary role in accounting for what balance of threat theory leaves out, namely, how states balance either bilaterally or multilaterally.

One major problem for political scientists in applying prospect theory to real-life, political events is how to set the reference point that defines the domains of gains and losses in case studies. Since there is no theory of framing or setting the reference point, IR scholars have introduced different techniques pragmatically to set a reference point for determining an actor's domain of gains or losses. As Mercer suggests, there are five major prevailing methods: using the status quo, using an aspiration level, employing heuristics, analogies, or emotions (Mercer, 2005: 4).

We choose the status quo as the reference point for determining domains of action for unitary actors (states) in the international system. Incorporating balance of threat theory, we specify the level of threat measured by material power, ideology, geographic proximity, offensive capabilities, and perceived intentions to identify the reference point and the 
domain of gains or losses for states (Walt, 1987: 5). When a state faces a high level of threat to its security, it is more likely to be framed as a situation in the domain of losses. On the other hand, when a state faces a low level of threat, it is more likely to be framed in the domain of gains. ${ }^{7}$

Most prospect theorists use subjective, emotional, and ideational factors to determine individual actors' domains of action. McDermott (1998: 37) suggests, 'domain can be relatively objective or subjective.... Framing in domain is restricted to a sense of whether the actor perceives himself to be acting from a position of gains or losses.' We measure external threat in both subjective and objective ways. On the one hand, objective measures of threats, such as military power and geographical proximity, are highlighted. On the other hand, ideational measures of threats, such as intentions and ideologies, are also emphasized. Leaders' perceptions about threats serve as a transmission belt to connect material threats and subjective fears in order to reflect the threat level as well as the respective domains of action for a state before alliance formation occurs. The framing effect of domain is reflected by policymakers' perceptions about the level of threats. Although some threats may not actually be serious enough to a state's security, policymakers' perceptions about the threat may have the framing effect of locating themselves in a domain of losses as a high threat.

How to operationalize level of risk is also a key question in applying prospect theory to political research. We follow McDermott's economic definition of risk and use the magnitude of the variance of the outcomes, that is, the range between the best and worse outcomes, to specify different levels of risk in state behavior in alliance formation. ${ }^{8}$ When facing external threats, states have two options in forming alliances. Bilateral alliances mean forging an alliance with only one other state, while multilateral alliances mean aligning with multiple countries. The best outcome for multilateral alliances is to get multiple military aid and support from multiple allies. However, a state in a multiple alliance will also incur multiple military and political constraints. For a stronger state, multiple constraints mean more obligations to weaker allies. For a weaker state, multiple constraints mean more bosses it has to follow and potential risks of abandonment. The variance between the best (security) and worst (freedom of action) outcomes for a multilateral alliance is indeed significantly greater. In contrast, if a state forms a bilateral alliance, it may not get as much military support for its security as it does in a multilateral alliance. The state also faces fewer political and military constraints compared to a multilateral alliance. The variance between the best and worst outcomes in a bilateral alliance is smaller than in a multilateral alliance. Consequently, the risk of forming bilateral alliances is also lower than joining multilateral alliances.

All other things being equal, the more alliance partners, the more risk (the greater variance between the best and worst outcomes) for the state. Under anarchy, states first prefer unilateral action, that is, self-help and no alliance, if they can handle external threats by their own efforts (Waltz, 1979). If they have to form alliances with other states for security, few partners are better than more partners for states because of the lower risk they have to incur on their freedom of action. It is true that states choose different alliances not only based on the quantity, but also on the quality, of potential allies. States want to form alliances with strong powers rather than weak powers. However, if a state has a choice between a bilateral alliance with one strong power and 


\begin{tabular}{|l|c|c|}
\hline & Weak Commitment & Strong Commitment \\
\hline Bilateral Alliance & 1 & 2 \\
\hline Multilateral Alliance & 2 & 4 \\
\hline
\end{tabular}

* The number in the cell indicates the relative risk propensity for different alliances. I is the smallest and 4 is the largest.

Figure I. Different alliance formations and risk propensities

a trilateral (multilateral) alliance with two strong powers, and if both types of alliances can provide similar security to the state, the bilateral alliance will always be the first choice for the state since the multilateral one is more risky to state autonomy. Therefore, applying prospect theory to alliance formation behavior suggests ceteris paribus that forming bilateral alliances is risk-averse behavior while constructing multilateral alliances is risk-acceptant behavior.

However, different types of alliances only tell part of the story in alliance politics. States can make loose, vague commitments and decrease the constraints of institutions on their behavior in multilateral settings, and they can also make serious, concrete commitments to increase constraints on the freedom of action within bilateral arrangements. Therefore, state commitments become another indicator that can measure states' strategic choices in different types of alliances. Figure 1 shows that there are four types of alliances based on the number of allies and the degree of commitments of states: (1) weakcommitment bilateral alliances, (2) strong-commitment bilateral alliances, (3) weakcommitment multilateral alliances, and (4) strong-commitment multilateral alliances. By using the features of these potential outcomes to assess risk levels, we can infer that strong-commitment multilateral alliances reflect the most risk-acceptant behavior while weak-commitment bilateral alliances indicate the least risk-acceptant (most risk-averse) behavior. Strong-commitment bilateral alliances and weak-commitment multilateral alliances are placed in the middle between the two extremes since they have similar intermediate risk levels.

Risk refers to the nature of states' policy choices, which is therefore defined separately from external threats to security that define the domain of choices. The level of risk of a state's alliance strategy is determined by the relative variance in autonomy associated with the choice. Generally, multilateral alliances are riskier than bilateral alliances, not because the former will bring more threats to the state's security, but because the former can bring greater benefits in security as well as greater costs in autonomy than the latter. In sum, by setting the level of threat as the reference point to determine the domain for states, we can infer the following general propositions: (1) if states face a high level of threat, then they are placed in a domain of losses and they are more likely to choose a multilateral alliance strategy with strong commitments to avoid further losses in security; and (2) if states face a low level of threat, then they are placed in a domain of gains and they are more likely to choose a bilateral alliance strategy with weak commitments to pursue gains in security. ${ }^{9}$

Applying this prospect-threat model to US alliance strategy after World War II in Asia, we deduce the following testable hypotheses: 
H1. When the United States faces a high level of threat, it will choose a multilateral alliance strategy with strong commitments.

H2. When the United States faces a low level of threat, it will choose a bilateral alliance strategy with weak commitments.

H3. When the threat level changes from low to high, the United States' alliance strategy will increase both in the number of allies and the extent of commitments.

To test these hypotheses, we conduct within-case comparison and process-tracing methods to examine why the United States did not form an Asian NATO in postwar Asia. ${ }^{10}$ Figure 2 shows a road map of the evolution of US alliance strategies in Asia from 1945 to 1954 specified by the prospect-threat alliance model. It is true that the United States did not form a NATO-type, multilateral alliance in Asia after World War II. However, it does not mean that the United States did not want to form an Asian NATO in the first place. After the Korean War the United States proposed a NATO-type alliance, the 'Pacific Pact', with other powers in Asia in order to deal with the increasing communist threats in Asia (H1), but it failed because its Asian allies rejected the US proposal of including Japan in the 'Pacific Pact'. After the Vietminh achieved a series of military victories against France in 1954, the United States once again proposed a NATO-type alliance, the 'united action', with Britain, France, and other Asian countries to block the imminent communist threats in Southeast Asia (H1 and H3). The US failed again because of opposition from Britain who did not share similar threat perceptions about communism. Consequently, the United States built a series of bilateral alliances and the loosely organized SEATO in the 1950s when the communist threats decreased after the Geneva Conference (H2 and $\mathrm{H} 3)$.

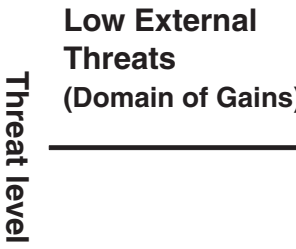

(June 1950)

High External

Threats

(Domain of Losses)

$\begin{array}{lll}\text { After Geneva Conference } & \text { Korean War } & \text { Vietminh's } \\ \text { (June 1954) } & \text { (June 1950) } & \text { Military }\end{array}$

Victories (1953)

\begin{tabular}{|c|c|c|c|}
\hline & SEATO (Sep 1954) & $\begin{array}{l}\text { The 'Pacific } \\
\text { Pact' Proposal } \\
\text { (Jan 1951) }\end{array}$ & $\begin{array}{l}\text { The 'United } \\
\text { Action' Proposa } \\
\text { (May 1954) }\end{array}$ \\
\hline $\begin{array}{l}\text { Risk-Averse } \\
\text { Behavior }\end{array}$ & & & $\begin{array}{r}\text { Risk-Taking } \\
\text { behavior }\end{array}$ \\
\hline $\begin{array}{l}\text { Weak Bilateral } \\
\text { Alliance }\end{array}$ & $\begin{array}{l}\text { Strong Bilateral or } \\
\text { Weak Multilateral Alliance }\end{array}$ & \multicolumn{2}{|c|}{ Strong Multilateral Alliance } \\
\hline
\end{tabular}

Figure 2. Prospect-threat model and US alliance strategies in postwar Asia 
It is worth noting that the prospect-threat model focuses on states' alliance formation behavior rather than the outcomes of states' foreign policies. In other words, we examine only why the United States chose different alliance strategies in Asia after World War II, not the outcome - either the success or the failure - of US strategies. Alliance formation is cooperative behavior among states. Although the United States is the driving force in forming different alliances after World War II, it does not mean that other countries' decisions do not matter. As indicated later in the SEATO case, one of the reasons for the failure of multilateral alliances in Asia is rooted in the divergent perceptions of threat between the United States and other countries in the region.

One tentative implication of the model, however, can be drawn regarding the outcomes of alliance formation. If key states in a region share a high level of threat, it is more likely for them to choose a multilateral alliance with strong commitments because these states are all placed in a domain of losses, which drives them to take more constraining risks in order to avoid further losses. Conversely, divergent threat perceptions among states make multilateral alliances difficult. ${ }^{11}$

\section{US alliance strategies in postwar Asia: The failed Pacific Pact and SEATO}

After World War II, the victory against Japan made the US one of the dominant powers in the Asia-Pacific. Before 1940, the United States was at best a secondary power in Asia where the European powers and Japan divided and colonized the region with coercive means. The key interests of the US in Asia focused on the Open Door policy, which facilitated the smooth economic interactions between the United States and the region. However, after defeating Japan in 1945, the US became a predominant power in the Asia-Pacific, and, consequently, its national security and interests were expanded and entrenched in Asia (Iriye, 1974).

The postwar international relations in Asia were largely shaped by the Yalta agreement between the Allied Powers. The United States occupied Japan and largely seized its sphere of influence in Northeast Asia and Pacific. The Soviet Union entered the Pacific War three months after Germany's surrender, and the US and Britain agreed to transfer the Japanese-owned Kurile Islands, the southern half of Sakhalin Island, as well as territorial rights and naval bases in Manchuria to the Soviet Union. China was still suffering the civil war between Nationalists and Communists. Neither the Soviet Union nor the United States had enough confidence to claim China into its sphere of influence due to the unclear future of China's civil war soon after World War II.

In Southeast Asia the Yalta agreement did not grant any privileges to the two superpowers. After the surrender of Japan the indigenous people strove for independence while the traditional colonial powers, such as France and Britain, tried to resume their colonial standing in Southeast Asia. The United States faced a political dilemma. On the one hand, the United States sympathized with the nationalist-independent movements in Southeast Asia. It granted the Philippines independence in 1946, encouraged the British to withdraw from India in 1947, and forced the Dutch to leave Indonesia in 1949. On the other hand, the United States was deeply worried that Moscow would gain advantage from the widespread revolutionary forces in the region. The United States tried to 
differentiate communists from nationalists in Southeast Asia but, in fact, the line between nationalism and communism in the decolonization movement in Southeast Asia was at best ambiguous. Consequently, despite its anti-colonial tradition the United States provided military and economic aid to the French who fought against the communist Vietminh in order to restore the colonial control of France in Indochina in 1950.

Compared to the power struggle between the United States and the Soviet Union in Europe, the US did not face the same degree of threat from the Soviet Union and other powers in Asia. First, the sole occupation right in Japan formed a solid economic and military foundation for the United States in postwar Asian security. Unlike a divided Germany that caused the inevitable confrontation between the United States and the Soviet Union, the US had absolute control in Japan after the war. The United States drafted a new constitution for Japan and conducted land and economic reforms to revitalize the Japanese economy. In addition, the United States turned Okinawa into the largest military base in the Asia-Pacific. Although the US occupation in Japan served the purpose of preventing the remilitarization of Japan soon after the war, it also strengthened the US ability to project its military power in the Pacific theater.

In contrast, the geographical distance between the centers of the Soviet war-making capacities in Europe and the Asian theater weakened Soviet threats and pressures on the US. As the Joint War Plans Committee of the United States concluded in August 1947, 'Soviet conquest of ... Asia would provide few military advantages and would not substantially increase their overall military capability' (Gaddis, 1987: 78). Although the Soviet Union occupied the Northern Islands after the war, it had to return Manchuria to China after 1949. The loss of the Manchurian base significantly eroded the Soviet ability to project its power in Asia.

In addition, advanced military technology and a nuclear monopoly offset the disadvantage of the lack of manpower of the United States in Asia. Although the Soviet Union and China had more manpower in mainland Asia, the US maintained its 'defensive perimeter' on the offshore islands in the Asia-Pacific. In 1948, George Kennan suggested the 'defensive perimeter' strategy in Asia, which argued that the US should not place its vital interests on the mainland of Asia. The US should instead rely on its preponderant naval and air capabilities to draw a strategic frontier on offshore islands, such as the Japanese islands, the Philippines, the Southeast Asian islands originally controlled by Britain and the Netherlands, as well as Australia and New Zealand. This 'defensive perimeter' strategy was widely endorsed by Washington. A CIA study in May 1949 also stressed the importance of the offshore islands in facilitating access to the strategic raw materials of India and Southeast Asia, especially if the Suez route should be closed (Gaddis, 1987: 74).

Given Soviet strategic impotence in Asia and China's internal turmoil after the war, the 'defensive perimeter' strategy of the United States provided sufficient security to the United States as a new emerging superpower in Asia. According to the prospect-threat alliance model, therefore, the United States was in a domain of gains in Asia because of the weak threats from the Soviet Union and China after the war. The model predicts that the United States should take less risky behavior to pursue more gains rather than more risky behavior to avoid losses in Asia. For the United States the further gains in Asia meant further control of the key offshore islands in the strategic chain of the 'defensive 
perimeter'. Given its preponderance of power, forming bilateral alliances was the first strategic choice for the US to exert control without constraining its freedom of action. Therefore, when Syngman Rhee, Chiang Kai-shek, and Elpidio Quirino proposed a multilateral collective security arrangement to the United States, the US rejected such a proposal because it would increase the economic and military costs of the US in regional security. In addition, the US believed that Rhee and Chiang were using Quirino to pressure the United States for a short-term military bail-out (Mabon, 1988).

However, the outbreak of the Korean War in 1950 shook the power equilibrium in Asia. Although Korea was not included in the US 'defensive perimeter' strategy, the military offensive by the North was largely interpreted as designed, aggressive behavior on the part of the Soviet Union. The status quo before the Korean War was challenged and, consequently, the United States was placed in a domain of losses. On the one hand, the United States had to send troops to the Korean peninsula to prevent communist expansion. On the other hand, the United States changed its previous anti-multilateralism attitude to pursue a 'Pacific Pact' with other non-communist states to prevent further losses to communist expansion in the region. After the Korean War, the previous 'KoreaTaiwan-Philippines' proposal was no longer on the table since the United States insisted on relying on the United Nations to deter the North's aggression (Brands, 1987). Taiwan was not included in the US consideration of alliances either since the United States did not want to be involved in another Chinese civil war (Christensen, 1996). Therefore, soon after the Korean War, the Pacific Pact proposed by the United States did not include either South Korea or Taiwan. Instead, the Pacific Pact proposal included Australia, New Zealand, Japan, and the Philippines, and possibly Indonesia.

In January 1951, John Foster Dulles traveled to Japan, Australia, and New Zealand to discuss the possibility of the creation of an offshore, defensive pact. Australia had proposed a multilateral defense arrangement with the major powers of the British Commonwealth as well as the United States soon after World War II. However, at that time, the United States was not yet prepared to commit itself to formal security arrangements in the Pacific. There were many reasons for the US reluctance, but one key factor was the lack of urgent/immediate threats in the Pacific. As David Mabon (1988: 150) suggests, '[Before the Korean War] the Russian threat to the area was real, but did not pose an immediate military problem', and, therefore, 'the United States was unwilling to assume fresh commitments'.

The outbreak of the Korean War, as suggested in our article, increased the urgency of US threat perceptions regarding the communist as well as potential Soviet threats. In January 1951, Dulles stated to the New Zealand ambassador that the previous US objections to a multilateral security arrangement had disappeared because 'the United States now clearly perceived Communist intentions on mainland Asia and was already involved in what would still be an unguaranteed area under the proposed pact' (cited by Mabon, 1988: 161). Although the US did not sell its Pacific Pact proposal in the broader Asia-Pacific region, its changing attitude toward multilateral defense arrangements coincided with Australia's and New Zealand's initial idea of a regional pact. For Australia and New Zealand, although they shared US frustrations about widespread communism in the region, they were more concerned about Japan's rearmament (Sissions, 1952). Therefore, they embraced the US idea of multilateral defense arrangements but did not 
want to include Japan. Great Britain strongly opposed inclusion of the Philippines in a regional defense pact led by the United States, which Australia and New Zealand were part of, because it would highlight Britain's exclusion and undermine British influence in the Pacific (Mabon, 1988: 171). The Philippines was also thereby excluded from this multilateral defense pact.

Consequently, the United States failed to form the Pacific Pact as it desired. Instead, the United States built bilateral alliances with the Philippines and Japan as well as a loose, trilateral treaty with Australia and New Zealand (ANZUS) in 1951 to strengthen its control of the strategic island chains in the Pacific. In other words, it was not the US intention to form bilateral alliances rather than a multilateral alliance soon after the Korean War. The strategic urgency from the Korean War forced the US to initiate the multilateral 'Pacific Pact', but it failed because of rejections from its potential allies. It was unwise for the US to initiate a defensive pact with Japan included as an ally. Since Japan had not resumed its sovereignty when the US initiated the 'Pacific Pact', it was not practical for the other Asian-Pacific powers to accept Japan in $1950 .{ }^{12}$

The dynamics of alliance formation in the cases of Korea, Taiwan, Japan, and the Philippines show the limits of US power in determining the final outcomes of alliance formation in Asia. It indicates that alliance formation is a collaborative enterprise, which is not determined by any individual state. The prospect-threat alliance model focuses on explaining the United States' alliance strategy, but its domain technically falls short of capturing the final outcomes of alliance formation in Asia in the postwar era. In addition, the above cases also indicate that the prospect-threat alliance model is better at accounting for great powers' alliance decisions than small countries' alliance behavior.

Besides East Asia, the Korean War also led the United States to reconsider its 'defensive perimeter' in Southeast Asia, which was seen as the weakest link of the US island chain strategy. In early 1950, the United States decided to extend military and economic aid to the French in Indochina. The rationale for this decision was that 'the loss of any of the countries of Southeast Asia to communist aggression would have critical psychological, political, and economic consequences ... would endanger the stability and security of Europe' (cited by Kim, 1981: 271). This was the preliminary version of the later 'domino theory' of Eisenhower in 1954. However, Southeast Asia was traditionally beyond the US sphere of influence. Britain and France, as traditional colonial powers, were cautious about US involvement in Indochina affairs although United States aid was seen as inevitable by France.

The deteriorating French situation against the Vietminh brought about both challenges and opportunities for the United States. On the one hand, the US was deeply worried that the victory of Ho Chi Minh in Vietnam would spread communism to Indochina and eventually to other Southeast Asian states. US policymakers also believed that the loss of Indochina would be an ideological and even military victory for Moscow against the global containment of the United States. In addition, the United States could not ignore the strategic importance of Southeast Asia as a source of food and raw materials in its island 'defensive perimeter' chain (Gaddis, 1987: 90). As the NSC 54/05 concluded on 6 January 1954, a French loss 'in addition to its impact in Southeast Asia and South Asia ... would have the most serious repercussions on US and free world interests in 
Europe and elsewhere' (Hess, 1990: 275). Moreover, the US security position in the Pacific, centered in the offshore island chain, would be jeopardized. Therefore, the serious consequences of the loss of Indochina put United States policymakers in a domain of losses. A more risky policy should be adopted to prevent further losses of the United States in Southeast Asia.

On the other hand, the military failure of France in Indochina was an unprecedented opportunity for the United States to legitimately become involved in Southeast Asian affairs. Although the United States was not a colonial power, like France and Britain who dreamed of resuming their colonial empires, the increasing military and economic capabilities expanded US interests to the Southeast Asian region after the war. Before the Indochina War the United States faced resistance from both Britain and France against its involvement in Southeast Asia. However, their rapid military defeat forced the French to seek support from the United States in early 1950. The United States was actually invited by the French to replace its dominant role in Indochina affairs.

Despite US military and economic aid, the French still failed to avert their defeat by the Vietminh. By late 1953, the French had begun to negotiate a settlement with the Vietminh. In early 1954, Britain and France - despite US objections — scheduled a conference with the Soviet Union and China to discuss the Indochina settlement as well as the Korean War in Geneva in the middle of 1954. Frustrated by the weakness of France and Britain in Indochina, the United States decided to take more risky action to stop communist expansion in Indochina.

In March 1954, after Dienbienphu was under siege by the Vietminh, Dulles proposed signing a Southeast Asian collective defense treaty with France, Britain, Australia, New Zealand, Thailand, the Philippines, and the Associated States in Indochina (Laos, Cambodia, and Vietnam) in order to conduct a 'united action' in countering both the Vietminh and the Chinese/Soviet threats. Dulles's initial plan was to form a NATO-type military alliance with an automatic response provision and a unified command in Southeast Asia (Buszynski, 1983: 16). Dulles's united action plan not only provided the United States with a legalistic reason to become directly involved in the Indochina War, but also served as a strategic deterrent against communists as NATO did in Europe. It was the US hope that the Vietminh would withdraw their troops after the declaration of the 'united action' led by the United States. Dulles's NATO-type 'united action' plan is also consistent with the prediction of the prospect-threat alliance model, which suggests that the US should take more risky action in a domain of losses in order to prevent further losses.

However, the 'united action' proposal of the United States failed to get support from the British and French. Both Britain and France intended to avoid large-scale military actions before the Geneva Conference. More importantly, the Soviet Union (under postStalinist leadership) and China announced a 'peaceful coexistence' policy with the West by calling for a reduction of tensions in Indochina. Britain and France worried that US intervention might not only escalate the situation and risk major war, but also erode their traditional influence in Indochina. Even though the French changed their negative attitude toward the US 'united action' proposal, due to the increasing military pressure in Dienbienphu, Britain insisted that the 'united action' plan should not be considered before the Geneva Conference. 
The US could not form a 'united action' with other regional powers before the Geneva Conference. Dulles's absence at the Geneva Conference was widely interpreted as resentment regarding Britain's negative attitude toward the 'united action' plan. In June 1954, Churchill visited Washington to coordinate Britain's policy with the United States about the Indochina settlement. The Geneva Conference seemed stagnant due to the inactive attitude of the US. Dulles finally made a deal with Churchill that the United States would support the partition of Vietnam while Britain should support the United States in forming a Southeast Asian treaty organization to prevent further communist expansion in Southeast Asia.

Under pressure from the Soviet Union and China, the Vietminh also made some concessions to the West. Finally, the Geneva Conference concluded with a division of Vietnam at the 17th parallel, and the communist Vietminh also withdrew troops from South Vietnam, Cambodia, and Laos. Since the partition granted the Vietminh legitimate control of Northern Vietnam, the Geneva Conference was seen as a disaster or diplomatic humiliation by many Americans (Buszynski, 1983: 15-16). Therefore, the United States continued to pursue the construction of a multilateral defensive treaty in order to deter further territorial losses to the communists in Indochina.

However, the Geneva Conference also alleviated military tensions in Indochina. The Vietminh's concession surprised the United States and other Western powers, because the Vietminh held an absolute military advantage after conquering Dienbienphu one day before the Geneva Conference. Even Dulles conceded privately that the communist demands had turned out to be relatively moderate in terms of their actual capabilities in the Geneva Conference (Hess, 1990: 279). Therefore, the Geneva Conference at least showed that the communist forces, the Soviet Union, China, and the Vietminh, did intend to reduce tensions and maintain coexistence with the West in Indochina. For the United States it meant that the communist expansion in Indochina would be halted at least temporarily after the Geneva Conference.

Although the United States was still interested in the 'united action' plan, the strategic goal of Washington was also changed by the Geneva Conference. Originally, the US feared the loss of the whole of Indochina because of the rapid military offensive of the Vietminh against the French. Therefore, the objective of the United States before the Geneva Conference was set at nothing other than a total 'military victory', which could possibly offset America's humiliation during the Korean War (Kim, 1981: 267). However, when the partition of Vietnam had become a reality after the Geneva Conference, the US started to consider a long-term plan to hold the division line rather than seek a whole victory against the Vietminh.

The change in US strategic goals, due to the moderated situation in Indochina, also influenced the prospect domain of US policymakers. The military victory of communists before the Geneva Conference made US decision-makers worry about the loss of Indochina and consequently the fall of dominos in Southeast Asia. Therefore, the United States was placed in a domain of losses consistent with Dulles's call for a 'united action' as a good example of a risky, multilateral commitment for the United States. However, after the Geneva Conference formulated a partition of Vietnam, the degree of urgency rooted in the communist aggression also dropped in Washington. In addition, after the Geneva Conference the nature of communist threats in the eyes of 
Washington's decision-makers also changed from direct military aggression to indirect subversion backed by the Soviet Union and China in Southeast Asia. The level of threat the US perceived also decreased dramatically. Consequently, US policymakers gradually moved from a domain of losses to a domain of gains. In other words, the United States could refuse to take any risky action for avoiding further losses because of the Geneva settlement. The United States was now more likely to consider how to gain more with relatively low risk.

One vivid example is Dulles's change of attitude regarding the 'united action' plan. After the Geneva Conference, Dulles pointed out that conditions in the region would not permit an alliance incorporating a NATO-type, automatic response (Buszynski, 1983: 17). In addition, the United States insisted on emphasizing 'communist threats or aggression' in the treaty in order to avoid involvement in internal conflicts among noncommunist countries in the region. Moreover, the United States refused to include any economic and military aid program in a future Southeast Asian treaty. Nor did the US support constructing an integrated central command in SEATO. Although Britain and France eventually persuaded the United States to agree to change the 'communist threats' to general military 'aggression', they failed to add any substantial military and economic aid program to the Treaty. Only three Asian countries, Thailand, the Philippines, and Pakistan, plus two pacific countries, Australia and New Zealand, finally participated in the Southeast Asian Collective Defense Treaty signed in September 1954, even though the protocol of the treaty extended to the three new Indochina countries, Vietnam, Laos, and Cambodia. ${ }^{13}$

Some scholars suggest that the less representative nature of the Asian members is the major reason for the weak strategic value as well as the final demise of SEATO, which is probably true. Through seeking help from Britain, the United States indeed tried, but eventually failed, to include the Colombo Powers (Ceylon, Burma, India, and Indonesia) in SEATO (Tarling, 2005). The 'Asian unique norm' argument suggested by Asian constructivists may offer more insights into why these Colombo powers, especially India, refused to join SEATO. However, SEATO's lack of representativeness is not the reason why the United States did not extend a NATO-type commitment to the SEATO countries. The United States could have made the same NATO-type commitments to other SEATO members if it had wanted to encourage more non-communist countries to join the alliance later. The power disparity argument is also not a major reason for the lack of US commitments. Britain, France, and Australia were all industrialized countries, and they all supported a more institutionalized defense structure within SEATO.

The major factor is the changed prospects for US policymakers regarding future gains in the context of the different degrees of threat from communism. Although the United States still supported forming a Southeast Asian defense treaty to prevent future communist aggression in Indochina, it was by no means willing to make any military and economic commitments other than a political warning under a less threatening situation after the Geneva Conference. For the United States, the Southeast Asian defense treaty (as Dulles admitted later) was more like the Monroe Doctrine, 'a moral offensive' with no standing military commitment, in the region (Tarling, 2005: 404). In other words, the treaty only served to claim a new sphere of influence of the United States in Southeast Asia. 
Given the weak commitment of the US as well as the internal differences between the United States and other major powers, especially Britain and France, it is no surprise that SEATO was an inherent failure in deterring the later communist expansion in Indochina. When the United States became fully committed to the Vietnam War in 1965, SEATO failed to help the United States gather military commitments of troops from Great Britain and France in Vietnam. After the Nixon Doctrine was announced in 1969, the United States started its strategic retreat from Southeast Asia. Although the US officially claimed to keep its commitments in Asia, including SEATO, its attitude toward SEATO became passive at best. In 1977, SEATO was officially disbanded due to its long-term impotency in regional security (Buszynski, 1983: 182-210).

\section{Conclusion}

Our findings suggest that the Korean War and Indochina War indeed posed high threats to the United States so that the United States seriously considered constructing NATOtype alliances in Asia. However, the inclusion of Japan doomed its 'Pacific Pact' proposal in East Asia, while the British rejection of the 'united action' plan before the Geneva conference killed a NATO-type Southeast Asian defense treaty in its infancy. Although SEATO was eventually established as a compromise between the United States and Britain, the United States refused to make NATO-type commitments in a relatively low-threat environment in Indochina after the Geneva settlement.

There are three major contributions of the prospect-threat alliance model in the study of alliance formation. First, it explains what realists cannot explain in the study of US alliance strategies. One of the criticisms of realist power disparity arguments in the NATO-in-Asia debate is that pure power considerations cannot explain why the United States included weak powers such as Iceland, Portugal, Turkey, and Greece in NATO but excluded Japan in its multilateral alliances in Asia after World War II. The prospectthreat model rather suggests that due to the high-level threats from the Soviet Union, the domain of losses faced by the United States in postwar Europe encouraged the United States to take more risks in forming a multilateral alliance with a strong commitment in Europe. The reason that the United States included weak powers in NATO as well as proposing the 'Pacific Pact' and the 'united action' with weak Asian allies is not to pool more resources as rationalists suggest, but to avoid future losses in the competition with the Soviet Union during the Cold War. This is a typical loss aversion behavior suggested by prospect theory (Levy, 1996). The prospect-threat model also indirectly endorses Taliaferro's balance of risk argument, which explains why great powers irrationally intervene in periphery wars.

Second, the prospect-threat model does not assume a state's preference or expected utility as neoliberals do. Therefore, the criticism of 'when multilateralism matters for the hegemon' on the institutional efficiency argument does not apply to the model. Moreover, the prospect-threat model suggests that the reason that the hegemon chooses multilateralism is not because multilateralism is a more efficient tool, but because the hegemon is willing to bear more risks under a domain of losses.

Third, the prospect-threat model does not answer the questions that constructivists failed to address in the study of US alliance formation, that is, the change of identity of 
the United States and the norm formation puzzle in Asia. However, the prospect-threat model highlights another ideational variable - threat perception — in shaping states' different alliance formation strategies. Building on Walt's balance of threat theory, the prospect-threat model specifies how states use alliances, that is, bilaterally or multilaterally, to cope with external threats based on states' prospects of future gains or losses. To a certain extent, the prospect-threat model bridges rationalism and constructivism through a psychological lens and complements the deficiencies of existing arguments in the study of alliance formation strategy.

The prospect-threat model agrees with balance of threat theory that the major purpose of alliance formation is to cope with external threats. ${ }^{14}$ However, different degrees of external threat shape the prospects of policymakers regarding a domain of gains or a domain of losses. Under high threat, decision-makers are framed in a domain of losses in that they are more likely to choose a risky behavior to avoid future losses. In choosing different alliances, states are more likely to make strong commitments to allies in a multilateral institutional setting. In contrast, if external threats are not high enough to alter the status quo, decision-makers are framed in a domain of gains. Consequently, states are more likely to make limited commitments and retain their freedom of action in a bilateral institutional setting. It should be noted that the institutional setting, that is, bilateral or multilateral, only reflects a certain feature of a state's commitment. A state may make very serious commitments to its bilateral ally, while it may make weak, vague commitments in a multilateral alliance.

In sum, US alliance commitments to its potential allies are a function of the external threats that it perceives. Applying the prospect-threat alliance model to post-Cold War world politics, we can understand why the United States was still interested in expanding NATO in Europe under the weak security threat from Russia as well as the severe implications for regional security. The low Russian threat after the Cold War placed the United States in a domain of gains so that the United States was more likely to choose a less risky policy to pursue gains. Enlarging NATO eastward was a less risky option after the Cold War in comparison with conducting a similar policy during the Cold War for the US, given the weak power of Russia after the Cold War. However, the NATO enlargement in Eastern Europe framed Russian leaders in a domain of losses because of the threat of pressure from NATO. Consequently, Russia was disposed to take a more risky stance in dealing with US threats. For instance, Russia's multiple-warheads missile test in 2007 and its military action in South Ossetia of Georgia in 2008 were riskier responses to US threats than simply protesting about the expansion of NATO.

By the same token, will there be a NATO in Asia in the future? It depends on how the United States perceives threats in Asia, especially the potential challenges from a rising China. The first trilateral summit among the United States, Japan, and Australia before the 2007 APEC meeting in Australia is widely seen as a pre-alliance gathering aimed at containing China's military threat (Kyodo News, 2007). If China's rise eventually provokes a region-wide threat shared by the United States and its Asian allies, an Asian NATO led by the US could drag Asia into another Cold War. However, if China's peaceful rise strategy (Zheng, 2005) can alleviate suspicions from others, an Asian Cold War is not inevitable. 


\section{Acknowledgments}

An early version of this article was delivered at the 103rd American Political Science Association Meeting, Chicago, 30 August-2 September 2007. The authors thank Stephen Walker, T.J. Pempel, Thomas Christensen, and anonymous reviewers of EJIR for their valuable suggestions and support.

\section{Notes}

1. Although many scholars correctly point out that the US should not take all the credit or blame for Europe's success and Asia's failure in multilateralism, it may very well be that different US alliance formation strategies in Europe and Asia in the postwar era are a major, if not the only, reason for the variation in regionalism in these two areas. For example, some scholars suggest a path dependency argument to explain why US security arrangements in the early postwar era influenced the later regional security architectures in Europe and Asia after the Cold War (see Duffield, 2001; Press-Barnathan, 2000/1; Segal, 1990).

2. Press-Barnathan $(2000 / 1)$ argues that the power disparity between the US and European powers was at the medium level and neither high nor low power asymmetry encouraged the US to pursue a multilateral security arrangement.

3. We appreciate one anonymous reviewer's suggestion of these two possible explanations.

4. It should be noted that Hemmer and Katzenstein suggest an eclectic approach by including some material variables, such as power consideration, in their explanation. However, the major variable in their argument is still the different identities between the United States and its partners in Europe and Asia.

5. Risk is defined as 1 minus the probability of gains with the probabilities of gains and losses as the two logical outcomes of choice summing to 1.0. For different conceptualizations of risk and uncertainty, see Milburn and Billings (1976) and Kirkpatrick et al. (1976).

6. For examples of prospect theory in International Relations, see Farnham (1994); Levy (1997); McDermott (1998); Taliaferro (2004a, 2004b); and Mercer (2005).

7. For similar usages of setting the status quo as the reference point, see McDermott (1998) and Taliaferro (2004a).

8. There are different models of risk orientation, which range from a full specification of utilities and probabilities to calculate risk to less specified models in which either probability or utility is specified as measuring risk, as in the case of McDermott's (employed in this article) use of variance in utilities without specifying probabilities (see McDermott, 1998: 39). For different models of risk orientation and calculation, see Gallhofer and Saris (1979).

9. We can also deduce a third proposition to specify states' alliance formation choices when they face a middle level of threat. To make our propositions compatible with prospect theory, we focus first on the two extreme alliance strategies (see Hypotheses 1 and 2) as risk-taking and risk-averse behaviors in this research. Then we advance a third hypothesis (see Hypothesis 3 ) to account for the middle-range contingency.

10. For the within-case comparison and process-tracing methods, see George and Bennett (2005).

11. We appreciate both reviewers' suggestions regarding these implications of the model.

12. Theoretically, it is worth noting that another possible explanation for US bilateral alliances with several Asian countries is that the US did not perceive the same level of threat it faced 
in Europe in the early 1950s. Therefore, the United States did not choose the most risky alliance strategy to form an Asian NATO. Instead, the US chose a less risky alliance strategy to negotiate a series of bilateral alliances in Asia. For state alliance strategies and risk propensities, see Figure 1.

13. The three Western countries in the treaty were the United States, Britain, and France. For SEATO's structure and its implications to its members' security, see Modelski (1962).

14. It should be noted that recent studies on alliances challenge the traditional function of alliances, that is, balancing against threats. Pressman (2008) and Cha (2010) suggest that states can use alliances, especially bilateral alliances, to constrain their allies' behavior or achieve the divide-and-rule strategic goal. While acknowledging the contribution of the alliance-as-constraint argument, we highlight the balance of threat function of alliances and argue that high-level threats do change US alliance preferences from bilateral to multilateral alliances in this research.

\section{References}

Acharya A (2005) Why is there no NATO in Asia? The normative origins of Asian multilateralism. Weatherhead Center for International Affairs, Working Paper No. 05-05: 1-54.

Brands H (1987) The Dwight D. Eisenhower administration, Syngman Rhee, and the 'other' Geneva Conference of 1954. Pacific Historical Review 56(1): 59-85.

Buszynski L (1983) SEATO: The Failure of an Alliance Strategy. Singapore: Singapore University Press.

Cha V (2000) Abandonment, entrapment, and neoclassical realism in Asia: The United States, Japan, and Korea. International Studies Quarterly 44(2): 261-291.

Cha V (2010) Powerplay: Origins of the US alliance system in Asia. International Security 34(3): 158-196.

Christensen T (1996) Useful Adversaries: Grand Strategy, Domestic Mobilization, and SinoAmerican Conflict, 1947-1958. Princeton, NJ: Princeton University Press.

Crone D (1993) Does hegemony matter? The reorganization of the Pacific political economy. World Politics (45)4: 501-525.

Duffield J (2001) Why is there no APTO? Why is there no OSCAP? Asia-Pacific security institutions in comparative perspective. Contemporary Security Policy 22(2): 69-95.

Farnham B (1994) Avoiding Losses/Taking Risks: Prospect Theory and International Conflict. Ann Arbor, MI: University of Michigan Press.

Gaddis JL (1987) The Long Peace: Inquiries into the History of the Cold War. New York: Oxford University Press.

Gallhofer IN and Saris WE (1979) Strategy choices of foreign policy decision makers. Journal of Conflict Resolution 23(3): 425-445.

George A and Bennett A (2005) Case Studies and Theory Development in the Social Sciences. Cambridge, MA: The MIT Press.

Grieco J (1995) The Maastricht Treaty, Economic and Monetary Union and the neo-realist research programme. Review of International Studies 21(1): 21-40.

Hemmer C and Katzenstein P (2002) Why is there no NATO in Asia? Collective identity, regionalism, and the origins of multilateralism. International Organization 56(3): 575-607.

Hess G (1990) The American search for stability in Southeast Asia: The SEATO structure of containment. In: Cohen W and Iriye A (eds) The Great Powers in East Asia, 1953-1960. New York: Columbia University Press, 272-295. 
Ikenberry GJ (2003) State power and the institutional bargain: America's ambivalent economic and scurity multilateralism. In: Foot R, MacFarlane SN and Mastanduno M (eds) US Hegemony and International Organizations. Oxford: Oxford University Press, 49-70.

Ikenberry GJ (2004) Hegemony and East Asian order. Australian Journal of International Affairs 58(3): 353-367.

Iriye A (1974) The Cold War in Asia: A Historical Introduction. Englewood Cliffs, NJ: Prentice Hall.

Kahneman D and Tversky A (1979) Prospect theory: An analysis of decision under risk. Econometrica 47(2): 263-291.

Kim YH (1981) American Frontier Activities in Asia: US-Asian Relations in the Twentieth Century. Chicago, IL: Nelson-Hall.

Kirkpatrick S, Davis DF and Robertson R (1976) The process of political decision-making in groups: Search behavior and choice shifts. American Behavioral Scientist 20(1): 33-64.

Kyodo News (2007) Japan, Australia, and the US Hold 1st Trilateral Summit. 8 September. Available at: http://asia.news.yahoo.com/070907/kyodo/d8rgsm500.html.

Levy J (1996) Loss aversion, framing, and bargaining: The implications of prospect theory for international conflict. International Political Science Review 17(2): 179-195.

Levy J (1997) Prospect theory, rational choice, and international relations. International Studies Quarterly 41(1): 87-112.

Mabon D (1988) Elusive agreements: The Pacific Pact proposal of 1949-1951. Pacific Historical Review 57(2): 147-77.

McDermott R (1998) Risk-Taking in International Politics: Prospect Theory in American Foreign Policy. Ann Arbor, MI: University of Michigan Press.

McDermott R (2004) Prospect theory in political science: Gains and losses from the first decade. Political Psychology 25(2): 289-312.

Mercer J (2005) Prospect theory and political science. Annual Review of Political Science 8: 1-21.

Milburn T and Billings R (1976) Decision-making perspectives from psychology: Dealing with risk and uncertainty. American Behavioral Scientist 20(1): 111-126.

Modelski G (ed.) (1962) SEATO: Six Studies. Vancouver: University of British Columbia Press.

Press-Barnathan G (2000/1) The lure of regional security arrangements: The United States and regional security cooperation in Asia and Europe. Security Studies 10(2): 58-65.

Pressman J (2008) Warring Friends: Alliance Restraint in International Politics. Ithaca, NY: Cornell University Press.

Russett BM (1968) Components of an operational theory of international alliance formation. Journal of Conflict Resolution 12(3): 285-301.

Schweller R (1994) Bandwagoning for profit: Bringing the revisionist state back in. International Security 19(1): 72-107.

Segal G (1990) Rethinking the Pacific. New York: Oxford University Press.

Sissions DCS (1952) The Pacific Pact. Australian Outlook 6(1): 20-26.

Synder G (1997) Alliance Politics. Ithaca, NY: Cornell University Press.

Taliaferro J (2004a) Balancing Risks: Great Power Intervention in the Periphery. Ithaca, NY: Cornell University Press.

Taliaferro J (2004b) Power politics and the balance of risk: Hypotheses on great power intervention in the periphery. Political Psychology 25(2): 177-211.

Tarling N (2005) Britain, Southeast Asia, and the Impact of the Korean War. Singapore: Singapore University Press. 
Walt S (1987) The Origins of Alliances. Ithaca, NY: Cornell University Press.

Waltz K (1979) Theory of International Politics. New York: McGraw-Hill.

Weber S (1992) Shaping the postwar balance of power: Multilateralism in NATO. International Organization 46(3): 634-680.

Weitsman P (2004) Dangerous Alliances: Proponents of Peace, Weapons of War. Stanford, CA:

Stanford University Press.

Zheng B (2005) China's 'peaceful rise' to great-power status. Foreign Affairs 84(5): 18-24.

\section{Biographical note}

Kai He is an Assistant Professor in the Department of Political Science at Utah State University. He was a postdoctoral fellow in the Princeton-Harvard China and the World Program at Princeton University (2009-10) and a Bradley fellow of the Lynda and Harry Bradley Foundation (2009-10). His publications have appeared in European Journal of International Relations, Security Studies, Review of International Studies, The Pacific Review, Journal of Contemporary China, Asian Security, Asian Perspective, and International Relations of the Asia Pacific. He is the author of Institutional Balancing in the Asia Pacific: Economic Interdependence and China's Rise (Routledge, 2009).

Huiyun Feng is an Assistant Professor of Political Science at Utah State University. She is a former Jennings Randolph Peace Scholar at United States Institute of Peace. Her publications have appeared in Security Studies, The Pacific Review, Chinese Journal of International Politics, and Asian Perspective. She is the author of Chinese Strategic Culture and Foreign Policy Decision-Making: Confucianism, Leadership and War (Routledge, 2007). 